\author{
Volkan Mutlu \\ Recep Tayyip Erdoğan University, Turkey
}

\title{
RELATIONSHIP OF PERSONALITY TYPES AND STRATEGY CHOICES IN FOREIGN LANGUAGE LEARNING ${ }^{27}$
}

\begin{abstract}
Summary. Language learning is a comprehensive concept with its components and needs. Because of this reason, it is affected by various subjects, most significant two of which are learner personality and language learning strategy choices of the students. By taking into consideration the importance of these factors in language education, the main aim of this study is to find out the relationship of students' personality types and their language learning strategy choices by also taking into account their language levels to provide information for syllabus designers and language teachers. In order to do this, a survey design method was supported with Myers and Briggs Personality Test and Oxford's SILL (Strategy Inventory for Language Learning), and 68 randomly selected students participated in this study. After analyzing the data with SPSS 23.0, it was found out that there is no significant statistical relationship between strategy choices and personality types. On the other hand, participants of this study showed different characteristics (most of them have ESTJ (extravert, sensing, thinking, judging) and they also desired to use different learning strategies, most used of which are compensation, memory, and social strategies. The study is crucial as it revealed that students could have different characteristics and learning strategies and these differences should be taken into consideration while planning a language course.
\end{abstract}

Keywords: personality types; SILL; learning strategy; Myers and Briggs.

\section{Introduction}

Learning which can be defined as "acquiring or getting of knowledge of a subject or a skill by study, experience, or instruction" (Brown, 2007, p. 7) or "the internalization of rules and formulas which can be used to communicate in the L2" (Tuncay, 2013, p. 119) needs the use of different strategies and is affected by various variables such as learner, teacher, and learning environment. As an essential variable, the learner should be given importance because it is nearly impossible to teach something if it is not desired by the learner herself/himself and learner characteristics are the main factors that should be taken into consideration in this respect. Examining and considering

27 Orally presented in $2^{\text {nd }}$ Black sea Conference on September 21-22 in Sinop, Turkey. 
the personalities of a group of learners will create positive effects while determining educational activities.

Bitlisli, Dinç, Çetinceli, and Kaygısız (2013) describe personality not only as the stable entity of the all characteristic features of a human being but also an invariable model of individual characteristics which define the uniqueness of a person. Writers also explain that the root of the word "personality" goes back to the Latin word "person" that means the mask used to represent the identity of the human beings and show their characteristics. These characteristics of human beings are not only usefull in their social life but also have influences on the academic life of the people by increasing or decreasing their learning capacity and time. Oxford (2003) thinks that the characteristics of an individual can be examined in four different ways as extraversion vs. introversion, thinking vs. feeling, sensing vs. intuition, and judging vs. perceiving. Extraverted learners get their energy and desire from the outside word and they learn by doing, discussing, or talking contrary to the introverted learners who choose to have just a few friends, focus on their own interests, and prefer to write instead of talking (Oxford, 2003 \& Report prepared for DORA ESFJ, 2013). It is understood from those studies that making extraverted students have writing activities or introverted students speaking exercises in front of the class will affect the learning atmosphere in a bad way and hinder the acquisition process because of decreasing the motivation and increasing the anxiety level. Planning a language class according to the students being extroverted or introverted can be helpful in expanding the language outcomes.

As a second characteristic type, sensing students like thinking about today and in which place they are. However, intuitive students are more imaginative and able to think in an abstract way. It is easy for intuitive students to find new theories or solutions for a problem and task-based language learning activities can be beneficial for those students. Asking those students to find the answer to a question or discover a grammatical point in L2 by accomplishing various tasks will get their attention. Nevertheless, sensing students are content with what they have, and they study on them. They do not desire to be active in the process of discovering the knowledge and are happy with studying the information that was already gathered for them. Another type of characteristics can be seen as the thinking vs. feeling. As 
understood from the titles, thinking students give importance to the truths even if these truths can be dangerous for them or other people. They desire to study the truths and reach the information in this way. Understanding grammatical or semantic rules of a language, and application of those rules can be a useful exercise for them. It is significant for the feeling students to consider their emotions in the learning process. They try to understand their friends' emotions or needs by showing empathy. Because of this reason, they do not have problems while working in pairs or groups. In the last group, judging students are more severe, and they need to find the solution as fast as possible. They want to be able to get part in the decision-making process of the learning activity. It is not easy for them to sit in the classroom and do what is asked from them. Contrary to the judging students who do not like activities such as games, it is easy for the perceiving students to obey all the rules that are decided by the teacher and they think everything in the world is a game. Because of this reason, it will be effective for them to learn by playing games or doing activities which will take hours or even days.

Table 1.

Myers-Briggs Type Indicator Personality Types

\begin{tabular}{|c|c|c|c|}
\hline Extroversion & Introversion & Sensing & Intuition \\
\hline $\begin{array}{l}\text { * Attuned to } \\
\text { external } \\
\text { environment } \\
\text { * Prefer to } \\
\text { communicate by } \\
\text { talking } \\
\text { * Work out ideas by } \\
\text { talking them } \\
\text { through } \\
\text { * Learn best } \\
\text { through doing or } \\
\text { discussing } \\
\text { * Have broad } \\
\text { interests } \\
\text { * Sociable and } \\
\text { expressive } \\
\text { * Readily take } \\
\text { initiative in work } \\
\text { and relationships }\end{array}$ & $\begin{array}{l}\text { * Drawn to their } \\
\text { inner world } \\
\text { * Prefer to } \\
\text { communicate in } \\
\text { writing } \\
\text { * Work out ideas by } \\
\text { reflecting on them } \\
\text { * Learn best by } \\
\text { reflection and } \\
\text { mental practice } \\
\text { * Focus in depth on } \\
\text { their interests } \\
\text { * Private and } \\
\text { contained } \\
\text { * Take initiative } \\
\text { when the situation } \\
\text { or issues is very } \\
\text { important to them }\end{array}$ & $\begin{array}{l}\text { * Oriented to } \\
\text { present realities } \\
\text { * Factual and } \\
\text { concrete } \\
\text { * Focus on what } \\
\text { is real and } \\
\text { actual } \\
\text { * Observe and } \\
\text { remember } \\
\text { specifics } \\
\text { * Build carefully } \\
\text { and thoroughly } \\
\text { toward } \\
\text { conclusions } \\
\text { * Understand } \\
\text { ideas and } \\
\text { theories through } \\
\text { practical } \\
\text { applications } \\
\text { * Trust } \\
\text { experience }\end{array}$ & $\begin{array}{l}\text { * Oriented to } \\
\text { future possibilities } \\
* \text { Imaginative and } \\
\text { verbally creative } \\
\text { * Focus on the } \\
\text { patterns and } \\
\text { meanings in data } \\
\text { * Remember } \\
\text { specifics when } \\
\text { they relate to a } \\
\text { pattern } \\
\text { * Move quickly to } \\
\text { conclusions, } \\
\text { follow hunches } \\
\text { * Want to clarify } \\
\text { ideas and theories } \\
\text { before putting } \\
\text { them into practice } \\
* \text { Trust inspiration }\end{array}$ \\
\hline
\end{tabular}




\begin{tabular}{|c|c|c|c|}
\hline Thinking & Feeling & Judging & Perceiving \\
\hline $\begin{array}{l}\text { * Analytical } \\
* \text { Use cause and } \\
\text { effect reasoning } \\
\text { * Solve problems } \\
\text { with logic } \\
\text { * Strive for and } \\
\text { objective standard } \\
\text { of truth } \\
\text { * Reasonable } \\
\text { * Can be "tough- } \\
\text { minded } \\
\text { * Fair.... Want } \\
\text { everyone treated } \\
\text { equally }\end{array}$ & $\begin{array}{l}\text { * Empathetic } \\
\text { * Guided by } \\
\text { personal values } \\
\text { * Assess impacts of } \\
\text { decisions on people } \\
\text { * Strive for } \\
\text { harmony and } \\
\text { positive interactions } \\
\text { * Compassionate } \\
\text { * May appear } \\
\text { "tenderhearted" } \\
\text { * Fair.... Want } \\
\text { everyone treated as } \\
\text { an individual }\end{array}$ & $\begin{array}{l}\text { * Scheduled } \\
\text { * Organize their } \\
\text { lives } \\
\text { * Systematic } \\
\text { * Methodical } \\
\text { * Make short } \\
\text { and long-term } \\
\text { plans } \\
\text { * Like to have } \\
\text { things decided } \\
\text { * Try to avoid } \\
\text { last minute } \\
\text { stresses }\end{array}$ & $\begin{array}{l}\text { * Spontaneous } \\
\text { * Flexible } \\
\text { * Casual } \\
\text { * Open minded } \\
\text { * Adapt, change } \\
\text { course } \\
\text { * Like things } \\
\text { loose and open to } \\
\text { change } \\
\text { * Feel energized } \\
\text { by last-minute } \\
\text { pressures }\end{array}$ \\
\hline
\end{tabular}

Note. From Myers-Briggs Type Indicator ${ }^{\circledR}$ Personal Impact Report (pp. 4-5), by Report prepared for DORA ESFJ. Copyright 2013, 4-5.

The characteristic features of all these personality types were examined and defined by Myers and Briggs and was called as MBTI, which is the combination of 8 different characteristics such as extroverted, introverted, thinking, feeling, sensing, intuition, judging, and perceiving. Those characteristics which were used to find out 16 different personality types and named by using the initials of individual characteristics (for instance; ISTJ, ENFJ, INFP, ENTP etc.) can be examined in Table 1 above.

As an information transferring activity, learning requires the use of different techniques which are named as learning strategies. These strategies are another important characteristic of the ELT procedures. Hardan (2013) cites the definition of Chamot (1982) and thinks that strategies are gadgets such as processes, techniques, approaches, and actions that are used in the learning by the learner. On this point, another concept comes into mind as learning styles. Before trying to explain the learning strategies in depth, it will be beneficial to make the differences of styles and strategies clear. As understood from Carson and Longhini (2002), learning styles are individuals' natural and habitual ways of acquiring the knowledge. The learner does not have a conscious choice of what to do and shows his/her characteristics in the learning process. Nevertheless, strategies which are intentional, and goal driven (Chamot, 2005) are deliberately chosen by the learner.

Learning strategies whose general characteristics are expressed by Patten and Benati (2010) as learner choice, awareness, purposeful, and 
laborious should be examined in detail as they are effective factors in the language education. These strategies have been grouped into two main categories which are direct and indirect learning strategies. According to Hardan (2013), Rebecca L. Oxford thinks that direct strategies are memory (need to produce mental images, employ audio and visual elements, and start actions), cognitive (that have such characteristics as studying, analyzing and giving reasons, and creating opportunities for comprehension and production), and compensation (trying to find out the next item and overcoming the speaking and writing barriers); while indirect strategies are metacognitive (related with planning and evaluating), affective (expressing the importance of emotions in the learning), and social (giving importance to the studying together and helping each other). Characteristics of all these strategies intensively explained in Table 2 below.

Table 2.

Characteristics of Learning Strategies

\begin{tabular}{|c|c|c|c|c|c|}
\hline \multirow{3}{*}{ 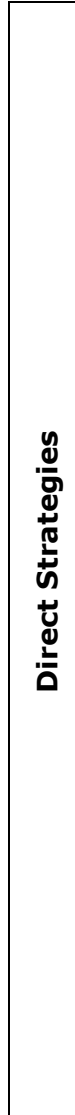 } & \multirow[b]{2}{*}{$\begin{array}{l}\text { Cognitive } \\
\text { Strategy }\end{array}$} & $\begin{array}{l}\text { - It needs } \\
\text { grouping, } \\
\text { imagination, and } \\
\text { reviewing. } \\
\text { - It is used for } \\
\text { storing and } \\
\text { retrieving the } \\
\text { information. }\end{array}$ & \multirow{3}{*}{ 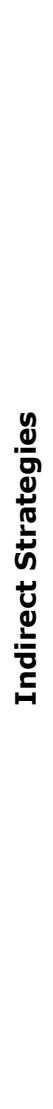 } & $\begin{array}{c}\text { Metacognitive } \\
\text { Strategy }\end{array}$ & $\begin{array}{l}\text { - It includes } \\
\text { planning, } \\
\text { evaluating, and } \\
\text { finding } \\
\text { opportunities. } \\
\text { le It helps } \\
\text { learners to control } \\
\text { their learning } \\
\text { process. }\end{array}$ \\
\hline & & $\begin{array}{l}\text { - It needs } \\
\text { reasoning, } \\
\text { notetaking, } \\
\text { outlining, } \\
\text { analyzing, and } \\
\text { explaining in a } \\
\text { short way. } \\
\text { - Its aim is to help } \\
\text { learner while } \\
\text { understanding the } \\
\text { target language } \\
\text { properly. }\end{array}$ & & $\begin{array}{l}\text { Affective } \\
\text { Strategy }\end{array}$ & $\begin{array}{l}\text { It is used to } \\
\text { lower the anxiety } \\
\text { and increase the } \\
\text { self-esteem and } \\
\text { motivation. } \\
\text { - While } \\
\text { Metacognitive } \\
\text { strategies control } \\
\text { the learning } \\
\text { processes, } \\
\text { affective } \\
\text { strategies control } \\
\text { the learner's } \\
\text { emotions. }\end{array}$ \\
\hline & $\begin{array}{c}\text { Compensat } \\
\text { ion } \\
\text { Strategy }\end{array}$ & $\begin{array}{l}\text { - It tries to help } \\
\text { the learner while } \\
\text { passing the } \\
\text { learning barriers. } \\
\text { - It enables the } \\
\text { learners to } \\
\text { compensate their } \\
\text { lack of vocabulary } \\
\text { and linguistic } \\
\text { knowledge. }\end{array}$ & & $\begin{array}{l}\text { Social } \\
\text { Strategy }\end{array}$ & $\begin{array}{l}\text { - It is helpful } \\
\text { for being able to } \\
\text { ask questions and } \\
\text { study in pairs or } \\
\text { groups. } \\
\text { - It helps } \\
\text { students to be in } \\
\text { an environment } \\
\text { where the L2 was } \\
\text { used. }\end{array}$ \\
\hline
\end{tabular}


Note. From "Assessing the Use of Language Learning Strategies Worldwide with the ESL/EFL Version of the Strategy Inventory for Language Learning (SILL)," by R. L. Oxford \& Burry-Stock, 1995, System, 23(1), "Language Learning Styles and Strategies: An Overview," by R. L. Oxford, 2003, GALA, "Language Learning Strategies: A General Overview," by A. A. Hardan, 2013, Procedia Social and Behavioral Sciences, 106.

It is obvious from the studies that learner characteristics and learning strategies are important factors in language education and not paying attention to those two items in the education process is not possible. Because of this reason, the aim of this study is to explain the importance of understanding students' individual characteristics, learning strategies, and the relationship of these items and arranging the learning environments according to these elements. Related to the main aim of the study, our research questions were developed as follows:

1. What is the result of personality tests of the students?

2. Which strategy do students use most?

3. How do students' strategy choices change according to their personality?

4. Do students' strategy choices show differences according to their language levels?

5. What is the relationship of MBTI and strategy choices?

\section{Method}

\section{Research design}

A Cross-Sectional Survey design was used in this study. It is a quantitative method and described by Cresswell (2005) as "procedures in quantitative research in which investigators administer a survey to a sample to the entire population of people in order to describe the attitudes, opinions, behaviors, or characteristics of the population" (p. 354). Dörnyei (2007) supports Cresswell by explaining the surveys' ability to show the characteristics of a population. In this survey design, it was aimed to understand students' characteristics and their strategy choices by asking them indirect questions. A Likert scale method was chosen to use in this study because it is a good method to collect opinions (McDonough \& McDonough, 1997). Likert scale method is appropriate for collecting and analyzing data collected with a survey. 


\section{Participants}

This study was carried with 68 students from different departments of a state university in Turkey. The study had 100 participants, but at the beginning some of the participants did not fill the survey forms completely, so they were excluded from the study. Having university students as participants also provided us with the chance of reaching individuals who are from different parts of the country and who have various characteristics. Students also do not have the same language levels as their levels can change from starter to intermediate.

\section{Data collection and data analysis}

Data were collected using two different survey forms which were designed and used in previous studies. In order to understand students' characteristics, Myers and Briggs Personality Test was used. This test includes four different sections and is used by the institutions or individual researchers to understand the characteristics of people. The sections of the test help us to understand students' characteristics as extraversion vs. introversion, thinking vs. feeling, sensing vs. intuition, and judging vs. perceiving and reach a final personality type. SILL (Strategy Inventory for Language Learning) was also used trying to categorize the students' learning strategy choices as cognitive, metacognitive, compensating, affective, social, and memory. SILL, which is the most used and efficient strategy scale to collect data in order to understand learners' strategy choices according to Oxford and Burry-Stock (1995) and used in other studies such as Park (1997), Bremner (1997), Griffiths and Parr (2001), and Yılmaz (2010), was used to collect data.

Table 3.

\section{Reliability Score of the Data Collection Tool}

\begin{tabular}{|c|c|}
\hline Cronbach's Alpha & N of Items \\
\hline .957 & 63 \\
\hline
\end{tabular}

SPSS 23.0 was used in the analysis processes of the quantitative data. Reliability score which can be found in Table 3 above proves the sufficiency and quality of the data collecting tools. As we have nonparametric data, descriptive 
statistic, Kruskal Wallis Test, and Regression analysis were applied to the data in the analysis process.

\section{Results and Discussion}

\section{Students' personality test results}

As it is evident from the findings presented in Table 4, most of the students in the study have sensing or thinking characteristics. These students are logical, fair, strict, trustful or they have the ability to remember the whole picture of the events, working on facts, and trusting their experiences. According to Rushton, Morgan and Richard (2007), sensing students think that their senses are important, and they want to study on concrete problems that can be understood quickly and thinking students wish to take objective decisions. Because of this reason, learning atmospheres of those students need to be prepared in a logical, strict, and trustful way. Students should feel insecure and games or activities which aims to relax the learner should not be used in the learning procedure.

Table 4.

Students' Personality Test Results

\begin{tabular}{|l|l|c|c|c|c|}
\hline \multicolumn{2}{|l|}{} & Frequency & Percent & $\begin{array}{c}\text { Valid } \\
\text { Percent }\end{array}$ & $\begin{array}{c}\text { Cumulative } \\
\text { Percent }\end{array}$ \\
\hline Valid & Extraversion & 1 & 1.5 & 1.5 & 1.5 \\
\cline { 2 - 5 } & Sensing & 23 & 33.8 & 33.8 & 35.3 \\
\cline { 2 - 6 } & Thinking & 22 & 32.4 & 32.4 & 67.6 \\
\cline { 2 - 6 } & Judging & 8 & 11.8 & 11.8 & 79.4 \\
\cline { 2 - 6 } & Sensing and thinking & 8 & 118 & 11.8 & 91.2 \\
\cline { 2 - 6 } & Sensing and judging & 3 & 4.4 & 4.4 & 95.6 \\
\cline { 2 - 6 } & Thinking and judging & 2 & 2.9 & 2.9 & 98.5 \\
\cline { 2 - 6 } & $\begin{array}{l}\text { Sensing, thinking and } \\
\text { judging }\end{array}$ & 1 & 1.5 & 1.5 & 100.0 \\
\hline
\end{tabular}

Students in this study are active and fact-minded. They can be practical while solving a problem or able to think in an analytical way because they have "ESTJ" (Extraversion, sensing, thinking, judging) MBTI type. People with this MBTI type are practical, realistic, and decisive (Myers, Kirby \& Myers, 2000) Teachers can be more successful in getting their students' attention and 
increasing the classroom success with a course design and a syllable which address students' common sense and critical thinking ability.

Table 5 .

\section{Students' Personality Test Results Divided into 4 Different Categories}

\begin{tabular}{|l|l|}
\hline Extraversion: 54 & Judging: 66 \\
Introversion: 14 & Perception: 2 \\
\hline Sensing: 64 & Thinking: 67 \\
Intuition: 4 & Feeling: 1 \\
\hline
\end{tabular}

As the students have extraversion characteristics, they need to be with other people and study with them. It is easy for them to learn when they are having peer or group works. Working alone or not being let to cooperate will be difficult for them. Assignments or homework which can be related to the social life and ask the students to communicate with others will motivate them and increase their course success. Because of being sensing, they trust facts more than anything else. Those students can be able to see the whole picture as a snapshot and remember them. However, studying on facts and relying on them too much decreases their chances of new possibilities. Explaining the classroom rules in a logical way and making the aim of the language course clear will motivate the students in this study and decrease their anxiety as they are carrying the characteristics of "thinking" people. Students who trust facts, like being with people, and are able to see the complete picture also want to have a chance of deciding something. Belonging to a group of "judging" people, they need to decide something in their studies. Educator should leave them blanks that can be completed with their decisions. In order to accomplish this, it will be better to study in a task-oriented way. A student-centred curriculum will work better with those students who are extraverted and judging.

\section{Students' SILL results}

Language teachers of the students who participated in this study must be aware that their learners mostly use compensating strategies. These strategies are used to solve the problems in the process of language education and exemplified by YIlmaz (2010) as switching the mother language or using the other clues. Students do something when they come across a problem or when 
they are hindered by a learning barrier. Learning with others and remembering strategies are others most used ones. Yılmaz (2010) also mentions that students try to group the language sounds or words in remembering strategies and need clarification as a social strategy (learning with others). There is no point for the teachers of those students to ask them to understand each other or connect the information by using their cognitive ability because students do not choose to use affective strategies or cognitive ones.

Table 6.

Students Strategy Choices

\begin{tabular}{|c|c|c|c|c|c|}
\hline & & Frequency & Percent & Valid Percent & $\begin{array}{c}\text { Cumulative } \\
\text { Percent }\end{array}$ \\
\hline Valid & Remembering & 13 & 19.1 & 19.1 & 19.1 \\
\hline & $\begin{array}{l}\text { Using mental } \\
\text { processes }\end{array}$ & 3 & 4.4 & 4.4 & 23.5 \\
\hline & Compensating & 17 & 25.0 & 25.0 & 48.5 \\
\hline & $\begin{array}{l}\text { Organizing and } \\
\text { evaluating }\end{array}$ & 12 & 17.6 & 17.6 & 66.2 \\
\hline & Managing emotions & 2 & 2.9 & 2.9 & 69.1 \\
\hline & Learning with others & 13 & 19.1 & 19.1 & 88.2 \\
\hline & $\begin{array}{l}\text { Remembering and } \\
\text { compensating }\end{array}$ & 1 & 1.5 & 1.5 & 89.7 \\
\hline & $\begin{array}{l}\text { Remembering and } \\
\text { organizing and } \\
\text { evaluating }\end{array}$ & 1 & 1.5 & 1.5 & 91.2 \\
\hline & $\begin{array}{l}\text { Using mental } \\
\text { processes and } \\
\text { organizing and } \\
\text { evaluating }\end{array}$ & 1 & 1.5 & 1.5 & 92.6 \\
\hline & $\begin{array}{l}\text { Managing emotions } \\
\text { and learning with } \\
\text { others }\end{array}$ & 2 & 2.9 & 2.9 & 95.6 \\
\hline & $\begin{array}{l}\text { Compensating and } \\
\text { organizing and } \\
\text { evaluating }\end{array}$ & 2 & 2.9 & 2.9 & 98.5 \\
\hline & \begin{tabular}{|l|} 
Using mental \\
processes and \\
compensating
\end{tabular} & 1 & 1.5 & 1.5 & 100.0 \\
\hline & Total & 68 & 100.0 & 100.0 & \\
\hline
\end{tabular}

In addition to the most used strategy types of the students, mean scores of the strategy choices express that students have an order of strategy using as compensating, remembering (memory), organizing and evaluating (metacognitive), learning with others, mental process (cognitive), and affective (managing emotions) strategies. It can be understood from this study that despite the increasing importance of humanity and methods which take into 
account the students' psychological side, affective strategies are the last used ones among the participants of the study. It is also clear in Yılmaz's study which was carried out in Çanakkale 18 Mart University that students use compensation strategies most and affective strategies least. Bremner (1999) is another researcher that expresses the high use of compensation strategies and low use of affective strategies. Students who took part in this research do not want to take into consideration their anxiety level or increase their motivation and self-esteem level in order to be successful and fulfil their tasks. The findings of the study support the results of other studies that compensation strategies are most often used strategies by the participants (e.g., Yılmaz, 2010; Bremner, 1999), and affective strategies are least common.

\section{Relationship of strategy choices and personality types}

Table 7.

\section{Kruskal Wallis Test Result}

\begin{tabular}{|c|c|}
\hline & general personality type \\
\hline Chi-Square & 5.957 \\
\hline df & 11 \\
\hline Asymp. Sig. & .876 \\
\hline
\end{tabular}

a. Kruskal Wallis Test

b. Grouping Variable: Most used strategy

After the examination of the data by using Kruskal Wallis test, it was understood that there is no statistical relationship between students' characteristics and their language learning strategy choices because the Asymp. Sig. Column has a value which is bigger than 0,05 . When the crosstab results of the same variables were examined, the reason for this low statistical relationship can be understood. It is clear from this analysis that most of the students have sensing or thinking characteristics and both of these groups use compensating strategies most.

Although all characteristic groups of the students use compensating strategies, students' second most used strategies show differences. Extraversion students' most often used strategies are compensating and remembering and their second choice is organizing and evaluating strategies. They like making plans and organizing their time for effective studying. Remembering and learning with others are the strategies which are following 
compensating strategies when the sensing, thinking, and judging students are taken into consideration. These students can work with other people on a task and be able to remember easily.

The information above made it certain that although no statistically significant differences were found between students' personality types and their language learning strategy choices, there are differences especially when the order of the strategy choices of the participants is examined from the most desired to the least desired. Because of this reason, it will be better for any language teacher to take into consideration students' characteristic features and their strategy choices while planning their courses. Students in this study desire to have some blanks to fulfil; namely, they need freedom to decide some parts of the activities and teachers should be careful about this situation if his/her learners have the same characteristics.

\section{Relationship of students' strategy choices and language levels}

Both Kruskal Wallis and Regression analysis were used to understand students' language level and strategy choice relationships. As understood from Table 8, the value in the Asymp. Sig. column of the Kruskal Wallis test is .117 which is bigger than .05. This value expresses that there is no statistically significant relation between the strategy choices and students' language levels, so it is estimated that there are no differences in the strategy choices of the students who have different language levels.

Table 8.

Kruskal Wallis of the Language Level and Strategy Choices

\begin{tabular}{|c|c|}
\hline & L2 Level \\
\hline Chi-Square & 16.693 \\
\hline df & 11 \\
\hline Asymp. Sig. & .117 \\
\hline
\end{tabular}

The R Square result of the Regression Analysis is ,038. It can be inferred from this value that there is ,038 percent relationship between students' language levels and their language strategy choices. The reason of this low relationship 
value is also students' high desire to use compensating strategies as most of the students wanted to use the compensating strategies initially.

Table 9.

Model Summary of Regression Analysis

\begin{tabular}{|l|r|r|r|r|}
\hline Model & R & R Square & Adjusted R Square & $\begin{array}{c}\text { Std. Error of the } \\
\text { Estimate }\end{array}$ \\
\hline 1 & $.194^{\mathrm{a}}$ & .038 & .023 & 2.88717 \\
\hline
\end{tabular}

a. Predictors: (Constant), L2 Level

\section{Students' Strategy choices and MBTI}

Table 10.

Kruskal Wallis and Regression Analysis Tests

\begin{tabular}{|l|l|}
\hline & $\begin{array}{l}\text { Students' real } \\
\text { personality } \\
\text { levels }\end{array}$ \\
\hline $\begin{array}{l}\text { Chi- } \\
\text { Square }\end{array}$ & 12.386 \\
\hline df & 11 \\
\hline $\begin{array}{l}\text { Asymp. } \\
\text { Sig. }\end{array}$ & .335 \\
\hline
\end{tabular}

a. Kruskal Wallis Test

b. Grouping Variable: Most used strategy

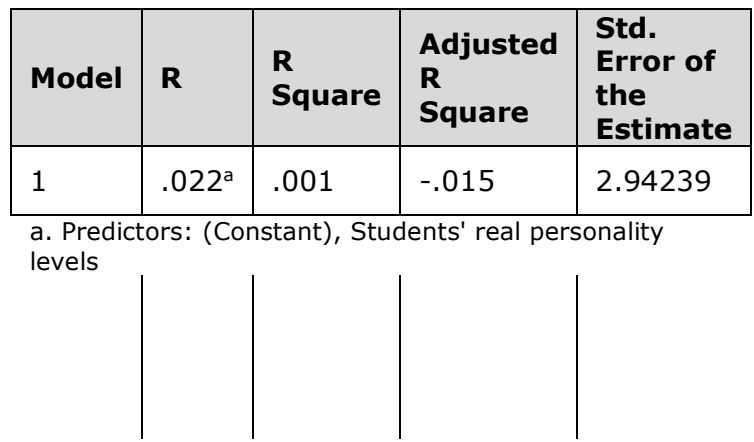

As understood from the results of the Kruskal Wallis Test and Regression Analysis, the relationship of students' MBTI and strategy choices is not meaningful because 50 of the 68 participants have "EST]" type of MBTI. The order (from the most chosen to the least one) of the learning strategy use of the students who have this type of MBTI is remembering (12 students), compensating (11 students), organizing and evaluating (10 students), and learning with others ( 9 students). This means most of the students try to remember the data that $s /$ he learned or they use strategies when they have missing information or knowledge (Crookall \& Oxford, 1989). The number of the students who use these strategies does not show big differences. Thus, the outcomes of the analysis do not show critical dissimilarities. Nevertheless, it is apparent that students who have ESTJ characteristics generally choose remembering, compensating, or metacognitive strategies. These students do not use the language learning strategies usually; they just try to plan their 
learning, remember their previous knowledge or struggle to pass the learning barriers.

\section{Conclusion}

Language learning is a challenging process, and both learners and learning strategies are the principal characters of this process. This study expresses the value of using the correct teaching methods and creating atmospheres according to students' personalities and learning strategy choices. It is understood that there is no direct and statistically significant relationship between students' personality traits and their strategy choices or language levels and strategy choices in opposition to Park (1997) who found a direct relation between learning strategies and TOEFL proficiency which especially supports the use of cognitive and social strategies. Nevertheless, this study revealed that students in the same class have different personality types and this affects their learning because of the different features of these personality types. Contrary to Oxford (2002) who mentions the high metacognitive and cognitive strategy use of successful learners in addition to affective strategies which are used by the students for whom the social side of the learning is given importance, our study revealed that participants generally use compensating strategies together with remembering strategies. Strategy choices of the students should be considered at the time of syllabus design. Another important point mentioned in the study was about the characteristics of the students.

Contrary to not being able to find any relationship between the students' characteristics and their language learning strategy choices, the study made it certain that students have definite tendencies about their characteristic features. It is difficult to have a group work with students who are introverts, and it is the responsibility of the teacher to find out this before starting the learning process. If the characteristic features of the students were not taken into consideration, teaching / learning activities would be difficult both for students and teachers. Since students will not be active in the learning process, and their self-esteem or motivation will be low.

Giving importance to the students learning strategy choices is also important. Contrary to the studies such as Carson and Longhini (2002) and Griffiths and Parr (2001) who support the high use of indirect strategies, our 
study revealed the excessively high use of direct strategies, especially compensation strategies. Students desire to use learning strategies when they come across a learning barrier. Strategies which are chosen deliberatively by the students have no relation with their personality but using the correct strategy in the learning process will have positive influences on learning. As expressed in the previous paragraphs, Oxford (2002) mentions the high use of cognitive strategies among successful students. Students who get high marks from the TOEFL exam generally adopt cognitive strategies. This study supports the idea that before preparing a learning curriculum or syllabus for a course, educators should take their students' personalities and strategy choices into consideration and not forget that students' personalities can show dissimilarities in different situations. Nunan (1988) thinks that teachers should identify learners' needs and group learners into different categories before starting the syllabus design process. It will be impossible to design the learning atmosphere according to personalities and strategy choices of all the students, but it can be possible to design this atmosphere according to the majority of the students' characteristics.

\section{References}

Bitlisli, F., Dinç. M., Çetinceli. E., \& Kaygısız. Ü. (2013). The relationship between five factor personality traits and academic motivation: A study on students of Isparta Vocational School Süleyman Demirel University. Suleyman Demirel University the Journal of Faculty of Economic and Administrative Sciences, 18(2), 459-480. Retrieved from http://dergipark.gov.tr/download/article-file/194329.

Bremner, S. (1999). Language learning strategies and language proficiency: Investigating the relationship in Hong Kong. Canadian Modern Language Review, 55(4), 490-515. doi.org/10.3138/cmlr.55.4.490.

Brown, H. D. (2007). Principles of language learning and teaching (5 th ed.). Newyork: Pearson.

Carson, J. G. \& Longhini, A. (2002). Focusing on learning styles and strategies: A diary study in an immersion setting. Language Learning, 52(2), 401438. doi.org/10.1111/0023-8333.00188. 
Chamot, A. U. (2005). Language learning strategy instruction: Current issues and research. Annual Review of Applied Linguistics, 25, 112-130. doi.org/10.1017/S0267190505000061.

Creswell, J. W. (2005). Educational research: Planning, conducting and evaluating quantitative and qualitative reseach (2nd ed.). New Jersey: Pearson.

Crookall, D. \& Oxford, R. (1989). Research on Language Learning Strategies: Methods, Findings, and Instructional Issues. The Modern Language Journal, 73(4), 404-419. doi.org/10.1111/j.15404781.1989.tb05321.x.

DORA ESFJ. (20 June 2013). Myers-Briggs Type Indicator Personal Impact Report European Edition. Retrived from http://assessio.nowpcontentuploads2017040PP_MBTI_Personal_Impact_Report_Verificatio n_English.pdf.

Dörnyei, Z. (2007). Research methods in applied linguistics. UK: Oxford.

Griffiths, C. \& Parr, J. M. (2001). Language-learning strategies: Theory and perception. ELT Journal, 53(3), 247-254. Retrieved from https://eric.ed.gov/?id=EJ629590

Hardan, A. A. (2013). Language learning strategies: A general overview. Procedia-Social and Behavioral Sciences, 106, 1712-1726. doi: 10.1016/j.sbspro.2013.12.194

McDonough, J. \& McDonough, S. (1997). Research methods for English Language Teachers. Newyork: Arnold.

Myers, I. B., Kirby, L. K. \& Myers, K. D. (2000). Introduction to type: A guide to understanding your results on the Myers-Briggs Type Indicator (4th ed.). UK: Oxford Psychologists Press.

Nunan, D. (1988). Syllabus design. New York: Oxford University Press.

Oxford, R. L. (2002). Language learning strategies in a nutshell: Update and ESL suggestions. In J. C. Richards, \& W. A. Renandya (eds.), Methodology in language teaching: An anthology of current practice (pp. 124-132). New York: Cambridge University Press.

Oxford. R. L. (2003). Language learning styles and strategies: An overview. GALA， 1-25. Retrieved from http://web.ntpu.edu.tw/ language/workshop/read2.pdf. 
Oxford, R. L. \& Burry-Stock, J. A. (1995). Assessing the use of language learning strategies worldwide with the ESL/EFL version of The Strategy Inventory for Language Learning (SILL). System, 23(1), 1-23. Retrieved from https://eric.ed.gov/?id=EJ506791.

Park, Gi-Pyo. (1997). Language learning strategies and English proficiency in Korean university students. Foreign Language Annals, 30(2), 211-221. Retrieved from https://onlinelibrary.wiley.com/doi/epdf/10.1111/ j.1944-9720.1997.tb02343.x

Patten, B. V. \& Benati, A. (2010). Key terms in second language acquisition. Great Britain: Continuum.

Rushton, S., Morgan, J. \& Richard M. (2007). Teacher's Myers-Briggs personality profiles: Identifying effective teacher personality traits. Teaching and Teacher Education, 23(4), 432-441. https://doi.org/10.1016/j.tate.2006.12.011.

Tuncay, H. (2013). ELT \& linguistics dictionary (2 ${ }^{\text {nd }}$ ed.). İstanbul: Yalın Yayıncılık.

Yılmaz, C. (2010). The relationship between language learning strategies, gender, proficiency and self-efficacy beliefs: A study of ELT learners in Turkey. Procedia Social and Behavioral Sciences, 2(2), 682-687. https://doi.org/10.1016/j.sbspro.2010.03.084. 


\section{Volkan Mutlu}

Radžepo Tajipo Erdogano universitetas, Turkija; volkan.mutlu@erdogan.edu.tr

\section{RYŠYS TARP ASMENYBĖS TIPO IR UŽSIENIO KALBOS MOKYMOSI STRATEGIJU PASIRINKIMO}

Santrauka. Kalbu mokymasis - tai sudetinga sąvoka, apimanti ivairius komponentus ir poreikius. Dèl šios priežasties ivairūs veiksniai turi itakos kalbu mokymuisi. Kaip vienus iš svarbiausiu galima išskirti asmenybès tipa ir kalbu mokymosi strategiju pasirinkima. Atsižvelgiant i šiu veiksniu svarba mokant(is) kalbos, pagrindinis tyrimo tikslas yra išsiaiškinti studentu asmenybės tipu ir kalbos mokymosi strategiju pasirinkimo santyki. Siekiant suteikti informacijos studiju programu sudarytojams ir kalbu mokytojams, tyrime taip pat atsižvelgiama i studentu kalbos lygius. Tyrime, sudarytame taikant tokius instrumentus kaip Myers-Briggs asmenybès testa ir SILL (Kalbos mokymosi strategiju inventoriu), dalyvavo 68 atsitiktinai atrinkti studentai. Išnagrinejus tyrimo duomenis, naudojant SPSS 23.0 programa, nustatyta, kad nèra žymaus statistiškai reikšmingo skirtumo tarp kalbos mokymosi strategiju pasirinkimo ir asmenybès tipu. Kita vertus, tyrimas atskleidè skirtingas dalyviu savybes (didžioji dalis yra ESTJ tipo asmenybès, kai dominuoja ekstraversija, sensorika, mastymas, vertinimas) ir ju polinki naudoti skirtingas mokymosi strategijas, iš kuriu dažniausiai pasitaiko kompensacinès, atminties ir socialinès strategijos. Šis tyrimas yra aktualus, nes atskleidžia, kad studentai gali turèti skirtingas asmenybès savybes ir naudoti skirtingas mokymosi strategijas, ir i šiuos skirtumus reikia atsižvelgti planuojant kalbos mokymo programas.

Pagrindinès sąvokos: asmenybès tipai; SILL strategiju inventorius; mokymosi strategijos; Myers ir Briggs. 